\title{
Metabolic Status of Dairy Cows Grouped by Anabolic and Catabolic Indicators of Metabolic Stress in Early Lactation
}

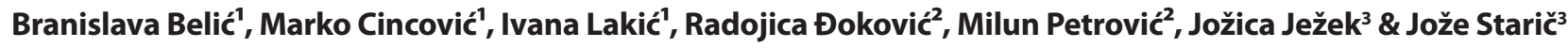

\begin{abstract}
Background: Early lactation is period followed by changed metabolism in organism of the cow. This is the consequence of negativ energy balance, metabolic stress and milk production. Early lactation is characterised by high lipide catabolism (high NEFA) and low anabolic capacity (low insulin and IGF-I concentration). The aim of this study is to examine differences in metabolic adaptation of cows in early lactation (eight weeks after calving) in accordance to anabolic (insulin, IGF-I) and catabolic (NEFA) indicators in first week after calving.

Materials, Methods \& Results: The experiment included 50 Holstein-Friesian cows. Blood samples were collected in first, second, fourth and eight week after calving by venepunction of v.coccigea. Based on median value of indicator, cows were significantly $(P<0.001)$ classified in two groups: cows under metabolic stress (indicators of anabolism below the median ${ }^{\mathrm{Me}}$ : indicators of catabolism above the median $^{\mathrm{Me}+}$ ) and cows in control group (indicators of anabolism above the median ${ }^{\mathrm{Me}}$ : indicators of catabolism under median ${ }^{\mathrm{Me}-}$ ). Following criteria for comparison were given: based on classification of cows according to one indicator of metabolic load (insulin ${ }^{\mathrm{Me}-}:$ insulin $^{\mathrm{Me}+} ;$ IGF-I $^{\mathrm{Me}-: \mathrm{IGF}^{\mathrm{Me}}}$ and NEFA ${ }^{\mathrm{Me} \cdot}: \mathrm{NEFA}^{\mathrm{Me}+}$ ); based on classification of cows according to combination of two indicators (insulin ${ }^{\mathrm{Me}-}+\mathrm{NEFA}^{\mathrm{Me+}}$ : insulin ${ }^{\mathrm{Me}+}+\mathrm{NEFA}^{\mathrm{Me}-}$ and $\mathrm{IGF}^{\mathrm{Me}-}+\mathrm{NEFA}^{\mathrm{Me}+}: \mathrm{IGF}^{\mathrm{Me+}}+\mathrm{NEFA}^{\mathrm{Me}-}$ ). Cows loaded with metabolic stress showed significan difference in metabolic adaptation in relation to control group $(P<0.05$ or $P<0.01)$ : higher values of STH, BHB (criteria were insulin, IGF-I, NEFA, insulin+NEFA, IGF-I+NEFA), higher values of bilirubin, AST, ALT, GGT, AP (criteria NEFA and IGF-I+NEFA) and MDA (criteria NEFA) and lower levels of glucose, total proteins, albumin (criteria IGF-I, NEFA, IGF-I+NEFA and body condition (criteria insulin, IGF-I, NEFA, insulin+ NEFA, IGF-I+ NEFA) were noted. Differences were expressed the most in first two weeks after calving. Differences in the body condition were the most notable later in weeks. Usage of NEFA indicator in first week after calving allows the most quality recognition of cows with metabolic parameters in extreme quartiles (ROC AUC $=0.87, P<0.01$ ) in first eight week of lactation.

Discussion: Inverse relation betwen NEFA with insulin and IGF-I is consequence of next phisiological concept: plasma insulin and IGF-I decrease in same mannure after calvig and insulin aplication increase IGF-I; low insulin concentration leads cow to lipolysis and low IGF-I leads to STH resistance with increase concentration of STH and high lipolysis. Catabolism of adipose tissue and high NEFA concentration is most important for metabolic adaptation in periparturient period. Cows with insulin resistance, ketosis and fatty liver with many problems in metabolic adaptation showed high NEFA concentration. Atenuation of NEFA by niacin or anti-inflammatory drug decreases metabolic change due to high lipide mobilisation in early lactation. Low antepartal IGF-I showed significant effect on postpartum health, but our measuremens are in first week postpartum. In addition, increase catabolism of lipide viewed in NEFA value contributes to metabolic variation and adaptation in the first eight weeks of lactation much more than decrease of anabolic indicators such as insulin and IGF-I. The combination of the indicators does not lead to better recognition of cows with extreme metabolic change in relation to classification only to the value of NEFA.
\end{abstract}

Keywords: cow, metabolism, anabolism, catabolism, Insulin Like Growth Fator I, NEFA.

http://dx.doi.org/10.22456/1679-9216.86476 
B. Belić, M. Cincović, I. Lakić, et al. 2018. Metabolic Status of Dairy Cows Grouped by Anabolic and Catabolic Indicators of

\section{INTRODUCTION}

Numerous metabolic adaptations occur in postpartum period in organism of dairy cows. Transition from dry period to lactation is supported by those adaptations. All signs of metabolic stress are present at this period. Reduced feed intake, negative energy balance, domination of catabolic processes and inflammation are those signs [28]. Domination of catabolic processes allows the body to produce energy from its own supplies. Fats are the crucial resources of energy because they deliberate highest energy levels in catabolic processes. Consequence of this catabolic process is lipolysis in early lactation with increased levels of NEFA into the bloodstream. Classification of cows according to lipid mobilization criteria can significantly affect value of white cells and hepatic enzymes [12]. Also, classification of cows according to values of NEFA and BHB can prove significant differences in metabolic and production adaptation of cows $[5,10,17]$. However, anabolic hormones decrease in same period. During early lactation cow showed lower concentrations of insulin (caused by reduced feed intake and reduced sensibility of receptors) and lower concentrations of IGF-I (reduced anabolic effect of STH in periphery tissues) [16]. Baldacim et al. [1] showed that pick of dinamic change of NEFA, insulin and IGF-I was at first week after calving.

The aim of this study is to examine influence of classification of cows according to anabolic (insulin and IGF-I) and catabolic (NEFA) parameters, in first week after calving on metabolic adaptation in first 8 week after calving.

\section{MATERIALS AND METHODS}

\section{Animals}

The experiment included 50 Holstein-Friesian cows. Cows were at the second and third lactation. No signs of health disorders in previous lactation were showed. Milk production was $7000 \mathrm{~L}$ per cow. Cows were raised at free system on deep litter. Transitional period was spent in tied system. Meals were controlled, but after giving birth cows were fed ad libitum. Water was given ad libitum. Mixed meals were given and they filled up all needs: corn silage (20-25 kg), alfalfa hay $(5 \mathrm{~kg})$, beet pulp $(3-5 \mathrm{~kg})$, concentrate $(5-7 \mathrm{~kg})$ and other additions were included at the meal. Following standards were satisfied: proteins (17.5-19.5\% SM crude proteins, $30-33 \%$ degradable proteins, 30-40\% non-degradable proteins), carbon-hydrates (ADF minimal $17-21 \%$, NDF minimum $28-31 \%$, NDF from forages minimum $18-23 \%$, nonstructural carbon-hydrates $35-42$, the level of dry matter from forages minimum 40-45\%), energy (NEL 7-7.4 MJ/ kg dry matter of the meal) and $5-7 \%$ fats in the meal.

\section{Blood sampling and laboratory procedures}

Blood samples were collected in first, second, fourth and eight week after calving. V. coccigea was punctured in period of 11-14 $\mathrm{h}$ to avoid influence of milking and also prandial effect on metabolites. Period of time between blood sampling and processing samples in laboratory was $3 \mathrm{~h}$. Blood samples were used immediately for laboratory analysis. Body condition was evaluated at the same tame as blood sampling.

Concentration of hormones and parameters of metabolic profile were examined in experimental period. Concentration of hormones was determined by standard ELISA kits for insulin, IGF-I, growth hormone-STH. ${ }^{1,2,3}$ Standard instructions given by producers were used. Concentrations were determined on Rayto 2100 c reader of micro titer plates ${ }^{4}$.

Metabolic profile was determined in every week when blood was sampled. Concentrations of NEFA, BHB and glucose were used to determine energetic status of cows. Protein metabolism was evaluated through concentration of total proteins, albumin, urea and ammonia. Cholesterol, triglycerides, total bilirubin, AST, ALT, GGT and AP were used to determine fat metabolism. These parameters were used to determined hepatic profile, too. Activity of SOD and MDA allowed determination of oxidative stress. Ione profile was examined by measuring concentrations of $\mathrm{Ca}, \mathrm{P}$ and $\mathrm{Mg}$. All parameters were determined by standard readi for use kits ${ }^{5,6}$. Standard kits from producers Randox (UK) and/or Pointe Scientific (USA) were used. Also, photometric reactions were performed. Biochemical tests were performed with Chemray automatic analyzer. ${ }^{4}$

Body condition was evaluated every week during the 8 weeks of experiment. Marks from 1 to 5 were given.

\section{Models and statistics}

Relations between cows classified according to median value of two indicators (one anabolic and one catabolic) and all used indicators were determined by Chi-square test. This was done after classification of 
cows in $2 \times 2$ tables. Based on median value of indicator, cows were classified in two groups: cows under metabolic stress (indicators of anabolism below the median Me-: indicators of catabolism above the median ${ }^{\mathrm{Me}+}$ ) and cows in control group (indicators of anabolism above the median ${ }^{\mathrm{Me}}$ : indicators of catabolism under median ${ }^{\mathrm{Me}}$ ). Following criteria for comparison were given: based on classification of cows according to one indicator of metabolic load (insulin ${ }^{\mathrm{Me}-}$ : insulin ${ }^{\mathrm{Me}+}$; ${\text { IGF-IMe-: } \text { IGF-I }^{\mathrm{Me}+} \text { and NEFA }}^{\mathrm{Me}}$ : $\mathrm{NEFA}^{\mathrm{Me}+}$ ) and based on combination of two indicators (insulin ${ }^{\mathrm{Me}-}+\mathrm{NEFA}^{\mathrm{Me}+}$ : insulin ${ }^{\mathrm{Me}+}+\mathrm{NEFA}^{\mathrm{Me}-}$ and $\mathrm{IGF}^{\mathrm{Me}-}+\mathrm{NEFA}^{\mathrm{Me}+}$ : IGF$\left.\mathrm{I}^{\mathrm{Me}+}+\mathrm{NEFA}^{\mathrm{Me}-}\right)$. Time influence on the parameters values during experimental weeks and influence of classification of cows according to values of metabolites and body condition were determined in every week. GLM was performed for this determination.

Influence of classification of cows by anabolic and catabolic indicators in recognition of poor metabolic adaptation was analysed by logistic regression and ROC curve was performed in the framework of logistic regression. Poor metabolic adaptation included cows with metabolic parameters in extreme zone with values above the upper quartile (for STH, BHB, bilirubin, AST, ALT, GGT, AP and MDA) or below the lower quartile (for glucose, total proteins, albumin, urea, cholesterol, triglycerides, SOD, Ca, P, Mg and body condition) in each particular week.

For statistic purpose SPSS satistic software were used $^{7}$. The level of significance was set at $P<0.05$.

\section{RESULTS}

Classification of cows in accordance with anabolic and catabolic criteria - Values of indicators of anabolism and catabolism were determined. Median, who was used as a limit for classification, showed following results: $0.37 \mathrm{ng} / \mathrm{mL}$ (insulin), $0.32 \mathrm{ng} / \mathrm{mL}$ (IGF-I), $0.66 \mathrm{mmol} / \mathrm{L}$ (NEFA). Based on median value of indicator, cows were significanlty classified in two groups: cows under metabolic stress (indicators of anabolism below the median ${ }^{\mathrm{Me}-}$ : indicators of catabolism above the median ${ }^{\mathrm{Me}+}$ ) and cows in control group (indicators of anabolism above the median ${ }^{\mathrm{Me}}$ : indicators of catabolism under median $\left.{ }^{\mathrm{Me}-}\right)$ in acordance to one or two $(P<0.001)$ criteria (Table 1$)$.

Influence of classification of cows on values of metabolic parameters was summarized in Table 2, with the classifications using one or two criteria yielded differences in metabolic parameters and body condition between the stressed and control group. For many number of parameters differences exist after classification acording to NEFA and NEFA+IGF-I, whereas clasification in acordance to insulin and IGF-I did not show difference in value of quite number of parameters.

Cows in metabolic stress (values of catabolic parameters above the median and anabolic below the median) have the following metabolic adaptations: higher values of STH, BHB (criteria insulin, IGF-I, NEFA, insulin+NEFA, IGF-I+NEFA), bilirubin, AST, ALT, GGT, AP (criteria NEFA and IGF-I+NEFA) and MDA (criteria NEFA). In contrast lower levels of glucose, total proteins, albumin (criteria IGF-I, NEFA, NEFA+IGF-I), urea, Ca, P (criteria insulin+NEFA), $\mathrm{Mg}$, SOD (criteria NEFA and cortisol), cholesterol, triglycerides (criteria insulin, IGF-I, NEFA, insulin+NEFA, NEFA+IGF-I) and body condition (criteria insulin+NEFA, IGF-I+NEFA, insulin, IGF-I, NEFA) were noted. The differences were the most noticeable in first two weeks after calving. In time, differences were reduced or completely gone. Body condition differences were notable in later weeks of experiment. Results are presented at Figure 1.

Usage of NEFA and NEFA+IGF-I indicator in first week after calving allows the most quality clasification of cows with metabolic parameters in extreme quartiles (ROC AUC for NEFA $=0.87, P<0.01$ and ROC AUC for IGF-I $=0.72, P<0.05$ ) [Figure 2].

Table 1. Significance of classification of cows based on anabolic (insulin, IGF-I) and catabolic (NEFA) criteria of metabolic stress and their combination (Insulin+NEFA, IGF-I+NEFA) on two groups: cows under metabolic stress (indicators of anabolism below the median Me-: indicators of catabolism above the medianMe+) and cows in control group (indicators of anabolism above the median $\mathrm{Me}+$ : indicators of catabolism under median Me-).

\begin{tabular}{ccccc}
\hline & NEFA $^{\mathrm{Me}+}$ & NEFA $^{\mathrm{Me}}$ & Chi sq & $P$ \\
\hline $\begin{array}{l}\text { Insulin }^{\mathrm{Me}+} \\
\text { Insulin }\end{array}$ & & 22 & 20,43 & $P<0.001$ \\
IGF- & 19 & & & \\
IGe+ & & 20 & $23 ., 21$ & $P<0.001$ \\
\hline
\end{tabular}


Table 2. Influence of a model by models with anabolic (insulin, IGF-I) and catabolic (NEFA) criteria of metabolic stress and their combination (Insulin+NEFA, IGF-I+NEFA) on blood metabolic parameters and BCS in the first eight weeks of lactation.

\begin{tabular}{|c|c|c|c|c|c|c|}
\hline \multirow{2}{*}{\multicolumn{2}{|c|}{ Insulin $^{1}$}} & \multicolumn{5}{|c|}{ Criterion of classification } \\
\hline & & Insulin $^{1}$ & IGF-I $^{2}$ & $\mathrm{NEFA}^{3}$ & $\begin{array}{c}\text { Insulin + } \\
\text { NEFA }^{4}\end{array}$ & $\begin{array}{l}\text { IGF-I + } \\
\text { NEFA }^{5}\end{array}$ \\
\hline \multirow{19}{*}{ 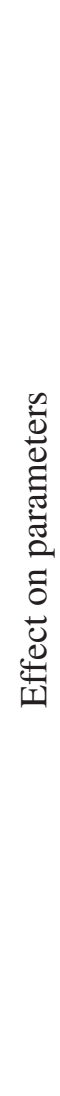 } & STH & $<0.01$ & $<0.01$ & $<0.01$ & $<0.01$ & $<0.01$ \\
\hline & Glucose & $\mathrm{NS}^{6}$ & $<0.01$ & $<0.05$ & NS & $<0.05$ \\
\hline & BHB & $<0.01$ & $<0.01$ & $<0.01$ & $<0,01$ & $<0.01$ \\
\hline & T.prot. & NS & $<0.05$ & $<0.05$ & NS & $<0.01$ \\
\hline & Albumins & NS & $<0.05$ & $<0.01$ & NS & $<0.01$ \\
\hline & Urea & NS & NS & $<0.05$ & NS & NS \\
\hline & AST & NS & NS & $<0.01$ & NS & $<0.01$ \\
\hline & ALT & NS & NS & $<0.01$ & NS & $<0.01$ \\
\hline & GGT & NS & NS & $<0.05$ & NS & $<0.01$ \\
\hline & AP & NS & NS & $<0.01$ & NS & $<0.01$ \\
\hline & Bilirubin & NS & NS & $<0.01$ & NS & $<0.01$ \\
\hline & Cholesterol & $<0.01$ & $<0.01$ & $<0.01$ & $<0,01$ & $<0.01$ \\
\hline & Triglycerides & $<0.01$ & $<0.01$ & $<0.01$ & $<0,05$ & $<0.01$ \\
\hline & MDA & NS & NS & $<0.01$ & NS & NS \\
\hline & SOD & NS & NS & $<0.01$ & NS & NS \\
\hline & $\mathrm{Ca}$ & NS & NS & $<0.01$ & NS & NS \\
\hline & $\mathrm{P}$ & NS & NS & NS & $<0,01$ & NS \\
\hline & $\mathrm{Mg}$ & NS & NS & $<0.05$ & NS & NS \\
\hline & BCS & $<0.01$ & $<0.01$ & $<0.01$ & $<0.05$ & $<0.05$ \\
\hline
\end{tabular}

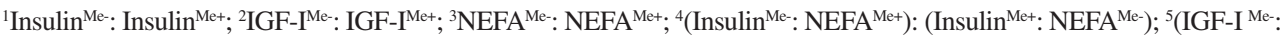
NEFA $^{\mathrm{Me}+}$ ): (IGF-I ${ }^{\mathrm{Me}+}: \mathrm{NEFA}^{\mathrm{Me}-}$ ); ${ }^{6} \mathrm{NS}-$ Statisticaly Non Significant $P \geq 0.05$.

\section{DISCUSSION}

Our results showed inverse relation between NEFA to insulin and NEFA to IGF-I relation in cows in first week after calving. Plasma insulin concentration declines in a same manner with the decrease in plasma IGF-I after parturition. Insulin infusion into early lactating cows increases plasma IGF-I concentration [18]. Low IGF-I stimulates somatotropic hormone on lipolysis [18]. Low antepartal IGF-I was important predictor of metabolic status of cows [26]. NEFA showed negative effect on insulin production and insulin sensitivity in aearly lactation [13]. NEFA is the crucial indicator of metabolic state in cows in early lactation, whic agrees with previous results $[5,10,12]$. NEFA values can predict health disorder in cows in early lactation [24]. Hachenberg et al. [12] showed that IGF-I concentration in addition to NEFA is not justified for evaluating the metabolic status. Our results are in relation with that conclusion.

Higher concentrations of STH were noted in group of cows that were under metabolic stress. Negative energy balance and metabolic stress cause higher concentration of STH [4]. STH and IGF-I are negatively correlated, so reduced concentrations of IGF-I can explain higher levels of STH in catabolic stressed group of cows (value of IGF-I is reduced) [22]. Insulin and STH can be considered as co-regulating hormones. Insulin is by his nature anabolic and homeostatic hormone. STH complete all conditions that homeoretic hormone should have (stimulate milk production, stimulate lipolysis etc.). This intensive relation is present because reduced levels of insulin in early lactation cause reduce of STH receptors and reduce of IGF-I concentration. Consequently, negative feedback 

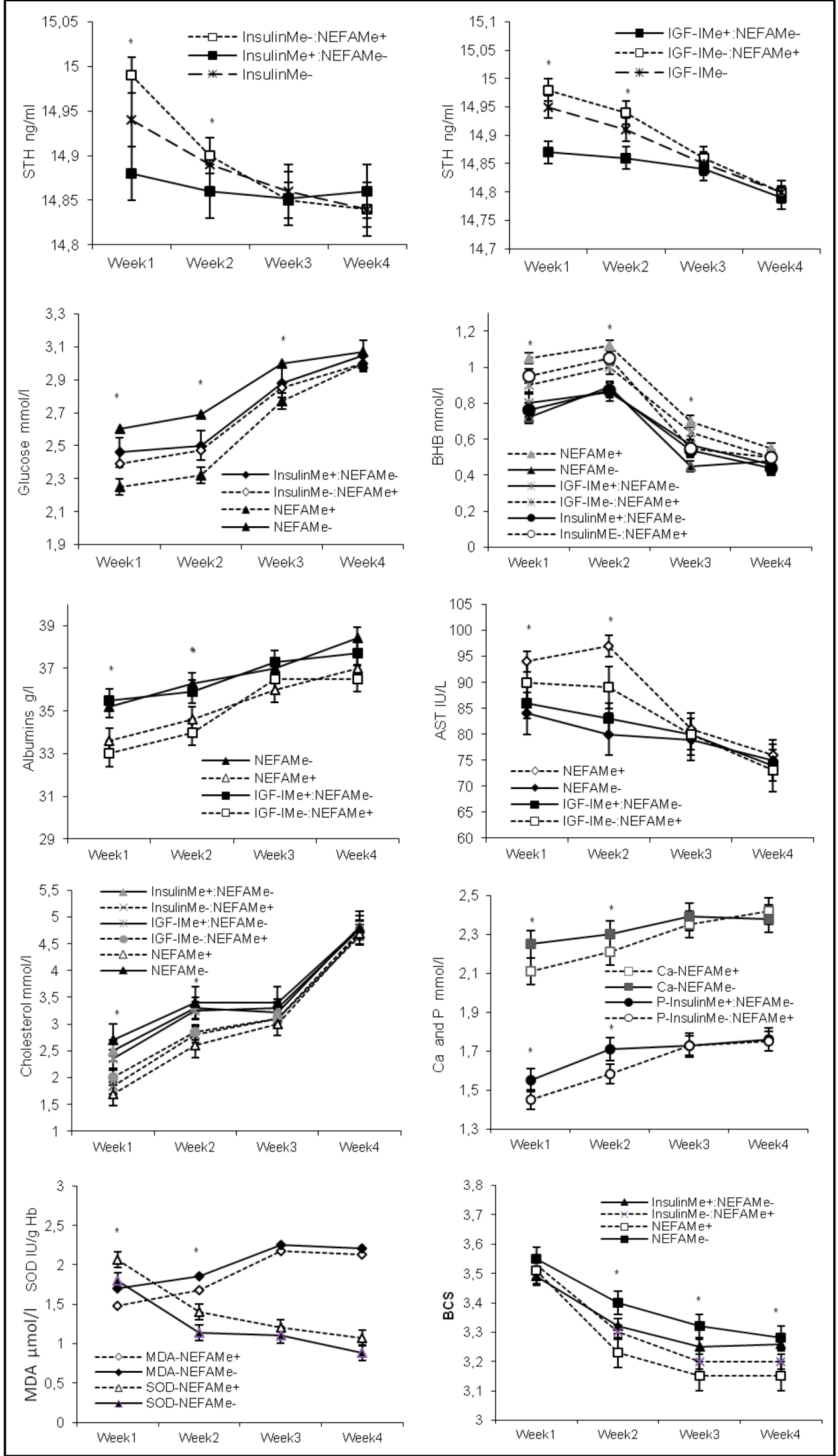

Figure 1. Mean $( \pm \mathrm{SD})$ concentration of metabolic parameters in blood and BCS from cows by models with anabolic (insulin, IGF-I) and catabolic (NEFA) criteria and their combination (Insulin+NEFA, IGF-I+NEFA). Asterisks indicate significant $(* P<0.01)$ differences in mean metabolite concentrations in catabolic loaded versus control group of cows in each week. 


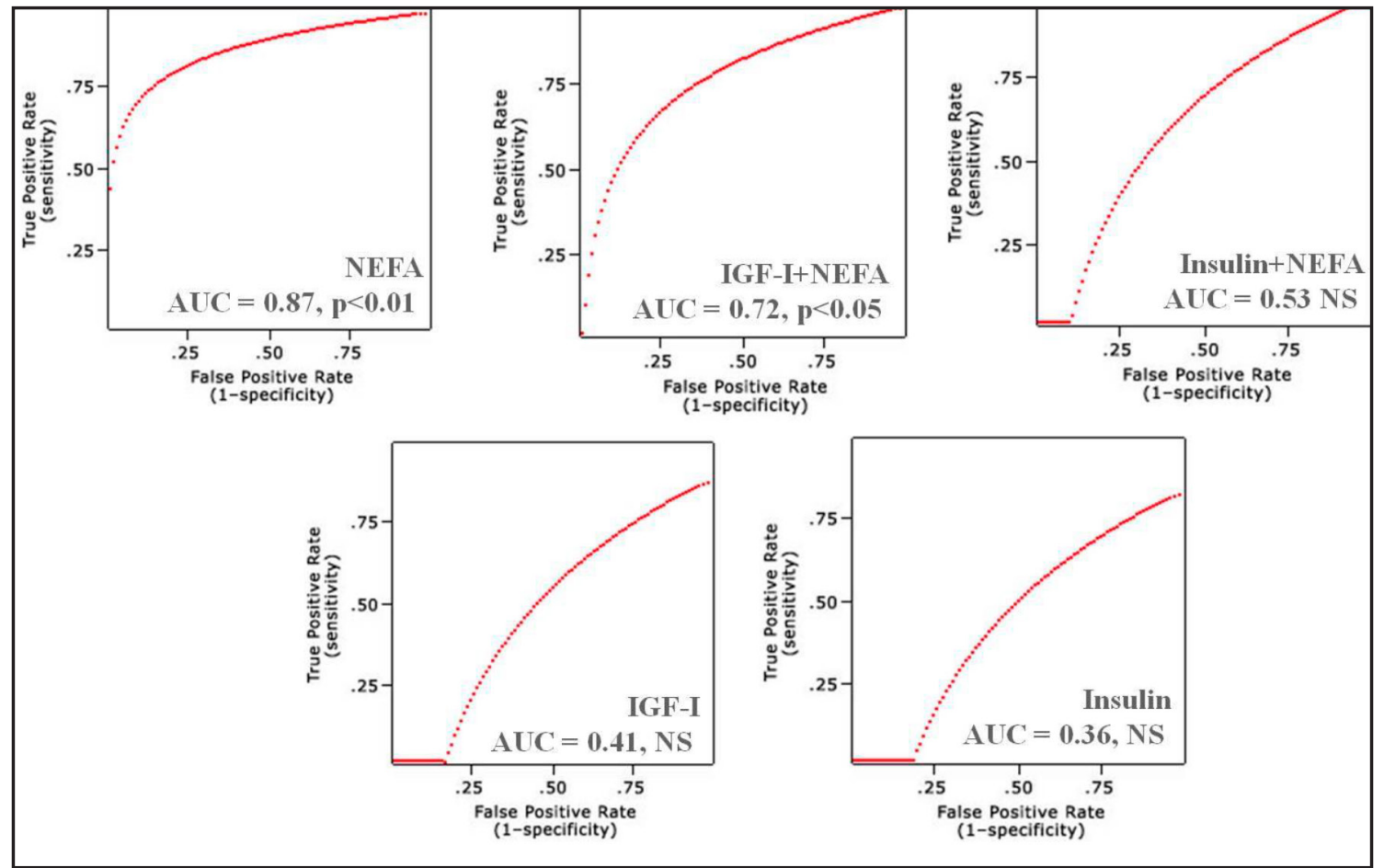

Figure 2. Area under ROC curve (AUC) for correct detection of cows with poor metabolic adaptation (value of metabolic parameters and BCS in extreme quartiles) in first eight week after calving by models with anabolic (insulin, IGF-I) and catabolic (NEFA) criteria and their combination (Insulin+NEFA, IGF-I+NEFA).

is not present. These adaptation processes depend on lactation period [11]. NEFA represent catabolic indicator and are directly proportional to STH concentration.

Lower levels of glucose in IGF-I ${ }^{\mathrm{Me}-}$ group can be explained by the fact that value of insulin, which regulates synthesis of IGF-I in the liver drops. Absence of IGF-I shuts down the feedback with STH, which concentration increase. Additionally, this affects milk production and consumption of glucose. This could be the reason that IGF-I has major influence like a stress indicator, but not include influence of insulin on glucose concentration. Correlation between insulin and STH is well known and use like common denominator in diabetes research. Researches include examination of people and cows in early lactation [21]. Ketosis expresses the same characteristics like metabolic stress in cows in our experiment. These characteristics are lower levels of IGF-I and insulin, but higher levels of NEFA [15].

Protein status in cows in early lactation depends on chosen indicators which are NEFA and IGF-I. Lower levels of proteinemia, albuminemia and urea concentrations were consequence of reduced feed intake (which is related to higher concentrations of NEFA) and reduced biosynthetic capacity of the liver (lower level of IGF-I). Urea concentration depended on NEFA only. Our results are consistent with earlier results that find lover levels of glucose, total proteins, albumin and urea [7,10]. Xu et al. [31] find that cows with clinical form of ketosis show reduced protein synthesis. This is the consequence of absence of elongating protein factors.

Results of functional status of hepatocytes are consistent with previous results that explain fatty liver phenomenon. NEFA show higher concentration, IGF-I and insulin show lower levels in cows with fat liver $[3,9]$. Fatty infiltration of hepatocytes is characterized by increased concentrations of bilirubin and higher activity of hepatic enzymes. Higher accumulation of triglycerides and absence of fat transport from the liver are the main reasons for reduced concentrations of cholesterol and triglycerides in the blood of cows [3]. Functional status of hepatocytes significantly depends on degree of lipid mobilization [10].

Reduced feed intake and negative energy balance (expressed naturally in early lactation) can cause oxidative stress [25]. In per partumperiod concentrations of pro-oxidative matters are in increase, but concentrations of antioxidants are in decrease. That is correlated with lipid mobilization. Moreover, it has been found that NEFA is in negative correlation with SOD activity. Positive correlation exists between NEFA and TBARS (which is in related with MDA) [2]. 
Higher concentration of NEFA and greater accumulation of triglycerides in hepatocytes in early lactation cause fat liver. Cows that have fat liver show higher concentrations of MDA and lower concentrations of alphatocopherol [23].

Status of ions also depends on indicators that were used in our experiment. Cows that express $\mathrm{Ca}$ concentrations above $2 \mathrm{mmol} / \mathrm{L}$ have lower concentrations of NEFA in early lactation, which our model shows [27]. Phosphorus concentration is in relation with insulin response and adipose tissue response during intravenous glucose tolerance test [6]. Low level of inorganic phosphorous is found in cows that have low concentration of insulin and high concentration of NEFA in ketosis [8].

Metabolic indicators in early lactation are correlated with body condition. IGF-I and insulin concentrations are positively correlated with body condition marks. In contrast, correlation with NEFA is not present [30]. Cows that were losing body condition (over 0.5 units) were showed significantly higher concentrations of NEFA and lower concentrations of insulin, liver lipidosis and reducing levels of IGF-I [20,29].

Catabolism of adipose tissue and high NEFA concentration is most important for metabolic adapta- tion in periparturient period. Atenuation of NEFA by niacin or anti-inflammatory drug decreases metabolic change due to high lipide mobilisation in early lactation $[14,19]$.

\section{CONCLUSIONS}

In conclusion, high catabolic load of lipide viewed as hihg concentration of NEFA will contribute in metabolic variation and adaptation in the first eight weeks of lactation much more than decrease of anabolic indicators as insulin and IGF-I.

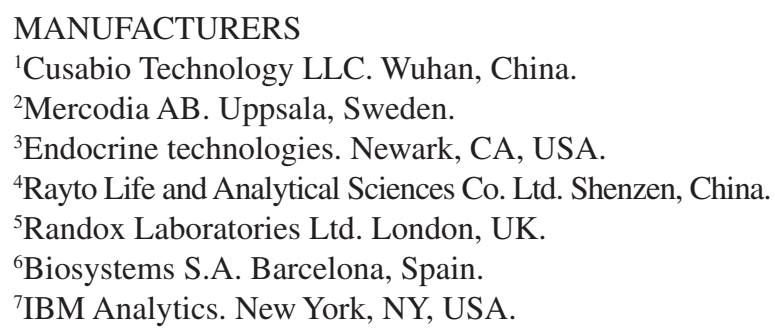

Funding. This research was supported by grants no. TR31062 from Ministry of education Serbia, science and technological development and Bilateral project Serbia-Slovenia.

Ethical approval. The Ethics Committee on animal use at University of Novi Sad (number IV-2017-02) approved this study. Declaration of interest. The authors report no conflicts of interest. The authors alone are responsible for the content and writing of paper.

\section{REFERENCES}

1 Baldacim V.A., Madureira K.M., Ramos J.S., de Silva C.P., Mori C.S., Dias M.R. \& Gomes V. 2018. Dynamic of Metabolic Indicators, Insulin Like-growth Factor I (IGF-I) and Cortisol in Holstein Cows during the Transition Period. Acta Scientiae Veterinariae. 46: 1544.

2 Bernabucci U., Ronchi B., Lacetera N. \& Nardone A. 2005. Influence of body condition score on relationships between metabolic status and oxidative stress in periparturient dairy cows. Journal of Dairy Science. 88: 2017-2026.

3 Bobe G., Young J.W. \& Beitz D.C. 2004. Invited Review: Pathology, Etiology, Prevention, and Treatment of Fatty Liver in Dairy Cows. Journal of Dairy Science. 87: 3105-3124.

4 Bradford B.J. \& Allen M.S. 2008. Negative energy balance increases peripheral ghrelin and growth hormone concentrations in lactating dairy cows. Domestic Animal Endocrinology. 34: 196-203.

5 Cincović M.R., Belić B., Radojičić B., Hristov S. \& Đoković R. 2012. Influence of lipolysis and ketogenesis to metabolic and hematological parameters in dairy cows during periparturient period. Acta Veterinaria (Beograd). 62: 429-444.

6 Cincović M.R., Djoković R., Belić B., Potkonjak A., Toholj B., Stojanac N., Stevančević O. \& Starič J. 2017. Inorganic phosphorus decrease after intravenous glucose tolerance test is associated with insulin resistance in dairy cows. Veterinarski Arhiv. 87: 409-418.

7 Djoković R., Ilić Z., Kurćubić V., Petrović M. \& Dosković V. 2011. Functional and morphological state of the liver in Simmental dairy cows during transitional period. Revue de Médecine Vétérinaire. 162: 574-579.

8 Djoković R., Šamanc H., Nikolić Z. \& Bošković-Bogosavljević S. 2007. Changes in blood values of glucose, insulin and inorganic phosphorus in healthy and ketotic dairy cows after intravenous infusion of propionate solution. Acta Veterinaria Brno. 76: 533-539.

9 Formigoni A., Cornil M.C., Prandi A., Merdenti A., Rossi A., Portetelle D. \& Renaville R. 1996. Effect of propylene glycol supplementation around parturition on milk yield, reproduction performance, and some hormonal and metabolic 
B. Belić, M. Cincović, I. Lakić, et al. 2018. Metabolic Status of Dairy Cows Grouped by Anabolic and Catabolic Indicators of Metabolic Stress in Early Lactation.

Acta Scientiae Veterinariae. 46: 1607.

characteristics in dairy cows. Journal of Dairy Research. 63: 11-24.

10 González F.D., Muiño R., Pereira V., Campos R. \& Benedito J.L. 2011. Relationship among blood indicators of lipomobilization and hepatic function during early lactation in high-yielding dairy cows. Journal of Veterinary Science. 12: 251-255.

11 Gross J., van Dorland H.A., Schwarz F.J. \& Bruckmaier R.M. 2011. Endocrine changes and liver mRNA abundance of somatotropic axis and insulin system constituents during negative energy balance at different stages of lactation in dairy cows. Journal of Dairy Science. 94: 3484-3494.

12 Hachenberg S., Weinkauf C., Hiss S. \& Sauerwein H. 2007. Evaluation of classification modes potentially suitable to identify metabolic stress in healthy dairy cows during the peripartal period. Journal of Animal Science. 85: 1923-1932.

13 Hayirli A. 2006. The role of exogenous insulin in the complex of hepatic lipidosis and ketosis associated with insulin resistance phenomenon in postpartum dairy cattle. Veterinary Research Communications. 30: 749-774.

14 Hristovska T., Cincović M.R., Belić B., Stojanović D., Jezdimirović M., Đoković R. \& Toholj B. 2017. Effects of niacin supplementation on the insulin resistance in Holstein cows during early lactation. Acta Veterinaria Brno. 86: 231-238.

15 Huszenicza G.Y., Kulcsar M., Korodi P., Bartyk J., Rudas P., Ribiczei-Szabo P., Nikolić Judith A., Šamanc H., Ivanov I. \& Gvozdić D. 2006. Adrenocortical and thyroid function, hormone and metabolite profiles and the onset of ovarian cyclicity in dairy cows suffering from various forms ketosis. Acta Veterinaria (Beograd). 56: 25-36.

16 Ingvartsen K.L. \& Andersen H.R. 2000. Integration of Metabolism and Intake Regulation: A Review Focusing on Periparturient Animals. Journal of Dairy Science. 83: 1573-1597.

17 Kessel S., Stroehl M., Meyer H.H.D., Hiss S., Sauerwein H., Schwarz F.J. \& Bruckmaier R.M. 2008. Individual variability in physiological adaptation to metabolic stress during early lactation in dairy cows kept under equal conditions. Journal of Animal Science. 86: 2903-2912.

$18 \mathrm{Kim}$ J.W. 2014. Modulation of the somatotropic axis in periparturient dairy cows. Asian-Australasian journal of animal sciences. 27: 147.

19 Kovačević Z., Cincović M., Stojanović D., Belić B., Jezdimirović M., Đoković R. \& Davidov I. 2016. Influence of Ketoprofen Application on Lipid Mobilization, Ketogenesis and Metabolic Status in Cows during Early Lactation. Kafkas Üniversitesi Veteriner Fakültesi Dergisi. 22: 7-12.

20 León H.V., Hernández-Cerón J., Keislert D.H. \& Gutierrez C.G. 2004. Plasma concentrations of leptin, insulin-like growth factor-I, and insulin in relation to changes in body condition score in heifers. Journal of Animal Science. 82: 445-451.

21 Lucy M.C. 2004. Mechanisms linking the somatotropic axis with insulin: Lessons from the postpartum dairy cow. Proceedings of the New Zealand Society of Animal Production. 64: 19-23.

22 Lucy M.C. 2008. Functional differences in the growth-hormone and insulin-like growth factor axis in cattle and pigs: implications for post-partum nutrition and reproduction. Reproduction in Domestic Animal. 43: 31-39.

23 Mudron P., Rehage J., Qualmann K., Sallmann H.P. \& Scholz H. 1999. A study of lipid peroxidation and vitamin E in dairy cows with hepatic insufficiency. Zentralblatt Fur Veterinarmedizin A. 46: 219-24.

24 Ospina P.A., Nydam D.V., Stokol T. \& Overton T.R. 2010. Evaluation of nonesterified fatty acids and -hydroxybutyrate in transition dairy cattle in the northeastern United States: Critical thresholds for prediction of clinical diseases. Journal of Dairy Science. 93: 546-554.

25 Pedernera M., Celi P., Garcia C.S., Salvin H.E., Barchia I. \& Fulkerson W.J. 2010. Effect of diet, energy balance and milk production on oxidative stress in early-lactating dairy cows grazing pasture. The Veterinary Journal. 186: 352-357.

26 Piechotta M., Holzhausen L., Araujo M.G., Heppelmann M., Sipka A., Pfarrer C., Schuberth H.J. \& Bollwein H. 2014. Antepartal insulin-like growth factor concentrations indicating differences in the metabolic adaptive capacity of dairy cows. Journal of Veterinary Science. 15: 343-352.

27 Reinhardt T.A., Lippolis J.D., McCluskey B.J., Goof J.P. \& Horst R.L. 2011. Prevalence of subclinical hypocalcemia in dairy herds. The Veterinary Journal. 188: 122-124.

28 Sordillo L.M. \& Raphael W. 2014. Significance of metabolic stress, lipid mobilization, and inflammation on transition dairy cows. Veterinary clinics of North America: Food Animal Practice. 29: 267-278.

29 Šamanc H., Gvozdić D., Fratrić N., Kirovski D., Djoković R., Sladojević Ž. \& Cincović M. 2015. Body condition score loss, hepatic lipidosis and selected blood metabolites in Holstein cows during transition period. Animal Science Papers and Reports. 33: 35-47. 
B. Belić, M. Cincović, I. Lakić, et al. 2018. Metabolic Status of Dairy Cows Grouped by Anabolic and Catabolic Indicators of Metabolic Stress in Early Lactation.

30 Wathes D.C., Cheng Z., Bourne N., Taylor V.J., Coffey M.P. \& Brotherstone S. 2007. Differences between primiparous and multiparous dairy cows in the inter-relationships between metabolic traits, milk yield and body condition score in the periparturient period. Domestic Animal Endocrinology. 33: 203-225.

31 Xu C., Wang Z., Liu G.W., Li X.B., Xie G.H., Xia C. \& Zhang H.Y. 2008. Metabolic Characteristic of the Liver of Dairy Cows during Ketosis Based on Comparative Proteomics. Asian-Australasian Journal of Animal Science. 21: 1003-1010. 